\title{
Perancangan Mobile Apps Panduan Pertolongan Pertama pada Kecelakaan untuk Orang Awam
}

\author{
Sarah Aghnia Husna dan Senja Aprella Agustin \\ Departemen Desain Produk, Fakultas Arsitektur Desain dan Perencanaan, \\ Institut Teknologi Sepuluh Nopember (ITS) \\ e-mail:sarahaghniahusna@gmail.com, senja@prodes.its.ac.id
}

\begin{abstract}
Abstrak-Pertolongan Pertama merupakan suatu tindakan penyelamatan agar kondisi korban tidak memburuk sebelum datang bantuan dari tenaga medis profesional. Pengetahuan mengenai pertolongan pertama ini merupakan hal yang sangat penting diketahui masyarakat dalam menghadapi situasi kegawatdaruratan. Masyarakat Surabaya sendiri sudah memiliki kesadaran akan pentingnya pengetahuan akan pertolongan pertama, namun media yang ada dirasa kurang mewadahi dari segi visualisasi, detail penyampaian instruksi dan bahasa yang sulit dipahami oleh orang awam. Konsep desain media pada aplikasi ini adalah komunikatif dan familiar, dimana aplikasi ingin menyampaikan informasi secara cepat dengan jembatan visual dan mengangkat materi sehari-hari. Konsep materi pada 'dos and don't's' sehingga memudahkan pengguna dalam menyerap informasi yang dipaparkan dalam aplikasi. Aplikasi ini telah melakukan serangkaian riset untuk memenuhi kebutuhan pengguna yaitu studi eksisting, depth interview, kuisioner, expert review, dan user testing. Aplikasi mobile instruksi medis pertolongan pertama ini akan diterapkan pada perangkat android dengan ukuran 5 inchi. Ilustrasi yang akan digunakan berupa gaya gambar komik menggunakan outline agar penyampaiannya ringan dan dengan konten teks yang singkat namun padat. Aplikasi ini telah berhasil dalam segi komunikatif sebesar $80,6 \%$ dan familiar sebesar $82,6 \%$ baik secara konten mupun media. Namun, masih ada pengembangan-pengembangan yang harus dilakukan ke depannya untuk membuat aplikasi ini semakin bermanfaat bagi masyarakat luas.
\end{abstract}

Kata Kunci-mobile apps, pertolongan pertama, panduan, situasi darurat.

\section{PENDAHULUAN}

A NGKA kecelakaan dalam ranah rumah tangga menduduki peringkat kedua setelah kecelakaan lalu lintas menurut data Kemenkes RI. Kepala Biro Humas Markas PMI, Aulia Ariani mengatakan, pertolongan pertama dalam rumah tangga penting sekali dan dapat dilakukan siapa saja selama memiliki ilmu. Dasar hukum dari pertolongan pertama ini adalah Pasal 531 K U H Pidana, "Barang siapa menyaksikan sendiri ada orang didalam keadaan bahaya maut, lalai memberikan atau mengadakan pertolongan kepadanya sedang pertolongan itu dapat diberikannya atau diadakannya dengan tidak akan menguatirkan, bahwa ia sendiri atau orang lain akan kena bahaya dihukum kurungan selama-lamanya tiga bulan atau denda sebanyak-banyaknya Rp 4.500 ,-. Jika orang yang perlu ditolong itu mati, diancam dengan : KUHP 45, 165, 187, 304 s, 478, 525, 566"

Namun, masyarakat cenderung belum memiliki pengetahuan akan pertolongan pertama. Sehingga banyak korban kecelakaan di jalan atau kejadian di rumah yang meninggal di perjalanan/saat menunggu pertolongan. Menurut Direktur Rumah Sakit Baptis, dr. Dolly Irbantoro, banyak masyarakat tak sadar bahwa sebenarnya penanganan yang keliru pada pertolongan pertama bisa berakibat fatal. Kebanyakan penolong tak memikirkan kondisi korban yang hendak ditolong. Banyak kejadian kecelakaan mobil atau motor dimana korban mengalami cedera/patah tulang belakang, ataupun tulang leher sebagai bagian sistem saraf pusat. Pertolongan terburu-buru dengan mengangkat korban secara sembarangan justru dapat memperparah kondisi patahnya tulang tersebut dan dapat beralibat fatal, salah satunya menyebabkan kecacatan dan bahkan kematian.

Selain kecelakaan yang umum terjadi di lingkungan seharihari, posisi Indonesia di ring of fire juga beresiko mengakibatkan terjadinya bencana, seperti gempa, banjir, tsunami dan kebakaran hutan. Namun, masyarakat Indonesia tidak pernah siap menghadapi bencana, baik bencana alam maupun bencana yang disebabkan oleh manusia sendiri. Padahal penanganan pertolongan pertama terhadap kecelakaan, baik akibat bencana alam maupun bencana yang disebabkan oleh manusia dapat meminimalisir jumlah korban dan tingkat keparahan korban, jika dilakukan dengan benar sesuai dengan prosedur medis.

Menurut hasil riset yang dilakukan oleh penulis terhadap 141 responden dengan rentang usia 18-35 tahuan, masyarakat Surabaya $76.6 \%$ pernah berada di situasi genting atau gawat darurat dan $44.4 \%$ di antaranya meminta pertolongan orang sekitar ketika terjadi keadaan genting, 20.6\% melakukan pertolongan pertama, $14.3 \%$ tidak berbuat apa-apa, $12.7 \%$ menghubungi fasilitas kesehatan dan sisanya menjawab lainlain. Hal ini menunjukkan bahwa masih banyak masyarakat Surabaya yang tidak tahu apa yang harus dilkaukan ketika terjadi situasi gawat darurat. Masyarakat menyadari pentingnya pengetahuan pertolongan pertama namun media yang ada dirasa kurang mewadahi dari segi kurangnya visualisasi, kurangnya detail penyampaian panduan, terlalu bertele-tele, sulit diingat dan bahasa dan teknik penyampaian yang sulit dipahami orang awam.

Aplikasi berbasis android, sebagai salah satu media yang sangat dekat dengan masyarakat saat ini dapat menjadi media yang dapat memenuhi kekurangan dari media sebelumnya yang dapat memberikan pengetahuan panduan kepada masyarakat, terutama masyarakat awam, mengenai pertolongan pertama pada situasi gawat darurat. Media aplikasi diharapkan dapat menjadi referensi dan rujukan informasi yang memudahkan masyarakat Indonesia dalam mengenal 
pengetahuan pertolongan pertama pada situasi gawat darurat sesuai dengan saran medis.

\section{A. Identifikasi Masalah}

1. Pertolongan pertama merupakan materi yang penting untuk diketahui masyarakat

2. Masyarakat banyak yang belum mengetahui ilmu pertolongan pertama

3. Media yang ada dirasa kurang dari segi visualisasi dan bahasa yang bertele-tele

\section{B. Rumusan Masalah}

Bagaimana merancang aplikasi panduan pertolongan pertama gawat darurat untuk masyarakat awam?

\section{Batasan Masalah}

Batasan masalah dalam perancangan ini adalah hanya membahas pengetahuan pertolongan pertama pada situasi gawat darurat yang diperbolehkan dilakukan masyarakat awam atas saran medis. Aspek-aspek desain yang digunakan dalam pembuatan aplikasi yaitu user interface, user experience, ikon, wireframe, tipografi, gaya ilustrasi, penggunaan elemen grafis dan warna.

\section{D.Tujuan}

Untuk menyediakan media panduan pertolongan pertama pada kecelakaan yang dapat menjadi rujukan dalam edukasi pengetahuan pertolongan pertama gawat darurat pada masyarakat.

\section{II.STUDI ACUAN}

\section{A. Landasan Teori}

\section{1) Pertolongan Pertama}

Pertolongan pertama adalah kegiatan yang dilakukan untuk memberikan pertolongan medis dasar untuk menyelamatkan jiwa penderita, mencegah cacat, memberikan rasa nyaman dan menunjang proses penyembuhan. Berdasarkan panduan PMI ada 23 pertolongan pertama yang dipelajari dalam kurikulum PMI

\section{2) User Interface}

User interface adalah sebuah tampilan tatap muka antara pengguna dan aplikasi. Metode - metode yang dapat digunakan untuk membuat suatu interface yang baik diantaranya fokus terhadap user, mengutamakan fungsi daripada desain, mempelajari perilaku pengguna, membuat desain untuk studi kasus yang umum, jangan mengalihkan pengguna dari tujuan yang akan diraih, memfasilitasi proses pemahaman dan pembelajaran suatu aplikasi, memberi informasi, tidak hanya data dan melakukan uji coba terahdap pengguna. Elemenelemen dalam UI yang harus diperhatikan diantaranya tipografi, icon dan warna.

\section{3) User Experience}

User experience adalah proses untuk meningkatkan kepuasan pengguna dengan meningkatkan aksesibilitas, usabilitas dan kepuasan yang disajikan melalui interaksi antara produk dengan pengguna. Prinsip-prinsip penting dalam UX diantaranya adopt (penggunaan splash screen, tips \& on boarding, homescreen \& navigation), use (penggunaan fitur pencari) dan return (desain yang menarik dan penyampaian konten yang efektif)

4) Ergonomi Visual dan Navigasi Lateral

Studi mengenai kebiasaan ornag berinteraksi dnegan smartphne menunjukkan bahwa $49 \%$ orang menggunakan smartphone dengan satu tangan. Schmidt melanjutkan studi Hoober dengan meneliti keterjangkauan area sentuhan bagi pengguna smartphone dengan satu tangan - yaitu tangan kanan dengan ukuran smartphone 5 inchi (ukuran mayoritas smartphone saat ini) dan disimpulkan bagian tengah dan bawah layar merupakan bagian yang paling cepat dijangkau[1]. Pada riset yang dilakukan Poynter, didapatkan hasil ketika pengguna melihat galeri dnegan orientasi potrait, $86 \%$ pengguna menggeser secara horizontal[2].

\section{5) Ilustrasi}

Ilustrasi menurut KBBI adalah gambar yang digunakan untuk memperjelas isi buku, karangan, dan sebagainya. Gaya ilustrasi model kartun bersifat simbolik dan biasanya menyederhanakan proporsi. Gaya ilustrasi ini dipilih karena penyampaiannya yang ringan dan sederhana sehingga membuat presepsi menyenangkan pada pengguna.

\section{B. Studi Eksisting}

\section{1) Aplikasi "PMI First Aid"}

Mobile apps native yang dapat diunduh gratis, tanpa iklan, relatif ringan, menggunakan animasi sederhana pada beberapaelemen dan dapat diakses offline.

\section{2) Aplikasi "Panduan P3K New Lengkap"}

Aplikasi berbasis e-book ini dapat diunduh gratis, relatif ringan, memiliki fungsi zoom dan dapat diakses secara offline. 3) Aplikasi "Buku Saku P3K"

Aplikasi berbasis $e$-book yang relatif ringan, dapat diunduh gratis, dan dapat diakses secara offline.

4) Aplikasi "First Aid White Cross"

Aplikasi hybrid yang dapat diunduh gratis, yang relatif ringan dan memiliki fitur emergency call tiap negara yang dapat terhubung dnegan dial pad.

5) Aplikasi "First Aid Unit"

Mobile apps native ini dapat diunduh gratis, relatif ringan, dapat diakses offline, terdapat fitur emergency call dan memiliki visualisasi berupa foto.

\section{METODOLOGI PENELITIAN}

\section{A. Metodologi Penggalian Data}

\section{1) Wawancara PMI Kota Malang}

Wawancara dilakukan dengan Bapak Aditya Bayu Wardana, S.Pd yang merupakan Staff Kepala Seksi Pelayanan PMI cabang Malang, mewakili Kepala PMI cabang Malang yang sedang bertugas di luar kota. Beliau saat ini aktif dalam kegiatan PMI khusunya di wilayah kota Malang. Dipilihnya PMI Kota Malang berdasarkan rekomendasi PMI Jawa Timur dimana PMI Malang merupakan PMI dengan pelatihan pertolongan pertama terbaik se-Indonesia. Dari wawancara ini didapatkan poin penting apa saja bentuk pertolongan pertama yang diperbolehkan dilakukakan orang awam, seberapa jauh sebenarnya PMI melakukan usaha penyebaran informasi 
pertolongan pertama dan acuan pertolongan pertama yang dapat diikuti oleh penulis.

2) Wawancara dengan Dokter Umum

Wawancara dilakukan dengan dr. Eri Sobari yang merupakan dokter umum di Malang. Beliau saat ini aktif melakukan praktek di klinik pribadi di wilayah Pasuruan. Dari wawancara ini didapatkan poin penting apa saja bentuk pertolongan pertama yang diperbolehkan dilaukakan orang awam menurut sisi kedokteran, memvalidasi data dari PMI, dan mendapatkan data obat-obatan yang diperbolehkan diberikan oleh orang awam.

\section{3) Kuisioner}

Pada perancangan ini dilakukan pengumpulan data dengan menggunakan kuisioner yaitu dengan memberikan pertanyaan yang akan dijawab oleh responden. Kuisioner digunakan untuk mengetahui pendapat responden mengenai objek yang diangkat dalam perancangan ini. Kuisioner ini nantinya menentukan konten yang dianggap paling penting, mendesak, dan sehari-hari untuk dibahas dalam perancangan ini.

\section{B. Metodologi Desain}

\section{1) Teori Pictogram}

Standarisasi penggunaan pictogram dalam dunia medis telah dikembangkan di berbagai negara, seperti Council of Japan pictograms, the United States Pharmacopiea Dispensing Information pictograms (USP) dan the International Pharmaceutical Federation (FIP) pictograms. Pada perancanagn ini, pictogram yang nantinya akan dikemabngkan emnjadi icon mengacu pada penggunaan pictogram the United States Pharmacopiea Dispensing Information pictograms (USP) karena gaya pictogramnya yang mayoritas juga menggunakan gaya line art dalam penyederhanaan bentuknya. Contoh pictogram dengan standar USP ditunjukkan pada Gambar

\section{2) Expert Review}

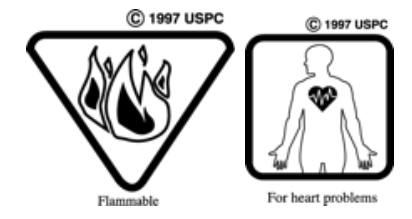

Expert review dilakukan pada M. Hilmy Fawwazy yang merupakan UI designer Traveloka. Expret review ini dilakukan untuk mendapatkan insight terhadap prototype yang telah dibuat dari segi user interface dan user experience.

\section{3) User Testing}

User testing dilakukan pada orang dewasa kisaran usia 3034 tahun di Surabaya untuk mengetahui pendapat calon pengguna mengenai aplikasi dan melakukan penilaian terhadap konsep aplikasi. Pada post test yang dilakukan, pertanyaan dibagi menjadi poin pertanyaan mengenai konsep komunikatif dan familiar, baik dari segi desain maupun penyampaian.

\section{4) Eksplorasi Desain}

Eksplorasi desain dilakukan pada perancangan desain dalam aplikasi. Eksplorasi dilakukan dalam merancang desain logo, desain ikon dan ilustrasi.

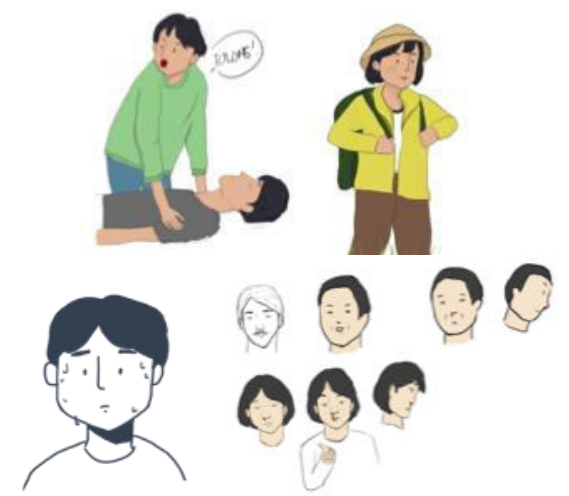

Gambar 1. Contoh eksplorasi gaya ilustrasi.

\section{KONSEP DESAIN}

\section{A. Konsep Luaran}

Hasil riset menghasilkan konsep luaran sebuah mobile apps dengan konten mengenai panduan pertolongan pertama pada kecelakaan untuk orang awam. Konsep desain keseluruhan aplikasi ini adalah 'you can help now' yang dapat diturunkan menjadi dua keyword yaitu komunikatif dan familiar. Untuk konsep penyampaian konten digunakan konsep 'dos and donts' dalam pemaparannya. Konten dalam aplikasi ini disampaikan melalui rangkaian ilustrasi yang telah didiskusikan secara medis. Mobile apps ini akan berjalan melalui sistem operasi Android dengan input perintah menggunakan touchscreen.

\section{B. Spesifikasi Teknis}

Berdasarkan pengamatan dan perbandingan terhadap objek eksisting yang sejenis, mobile apps ini dikerjakan dengan dimensi 720x1280 pixel dan resolusi 72 dpi. Spesifikasi smartphone yang dianjurkan untuk menjalankan buku digital ini minimal bersistem operasi Android 4.4 Jelly Bean.

\section{Konsep Materi}

Konsep materi yang akan disampaikan dalam aplikasi merupakan turunan dari big idea: "you can help now!". Merujuk pada pengguna yang merupakan orang awam dalam dunia medis, konsep materi yang dibuat adalah konsep "dos and don 'ts" dimana pengguna akan disajikan informasi berupa hal-hal yang harus dilakukan dan seharusnya tidak dilakukan namun sering terjadi dalam memberikan penanganan pertolongan pertama. Hal ini masih merupakan bagian dari big idea aplikasi, dimana dengan ditampilkan materi dengan konsep "dos and don'ts" pengguna dapat lebih mudah memahami materi dan melakukan pertolongan pertama sesegera mungkin.

Dalam penggunaan warna untuk konten ilustrasi, digunakan warna biru tua sebagai warna dasar ilustrasi, warna merah untuk menandakan materi yang bersifat larangan dan warna kuning untuk menandakan konten yang bersifat benar atau anjuran. Penggunaan satu warna sebagai warna dasar ilustrasi ditujukan agar pengguna fokus pada bentuk dan panduan yang 
diberikan sehingga memudahkan transfer informasi. Selain itu, penggunaan warna merah dan kuning sebagai penanda anjuran dan larangan dirasa dapat menonjol dan menarik perhatian pengguna sehinga materi tersebut benar-benar mendapatkan sorotan.

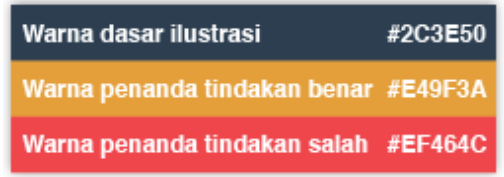

Gambar. 2 Palet warna ilustrasi Saraya.

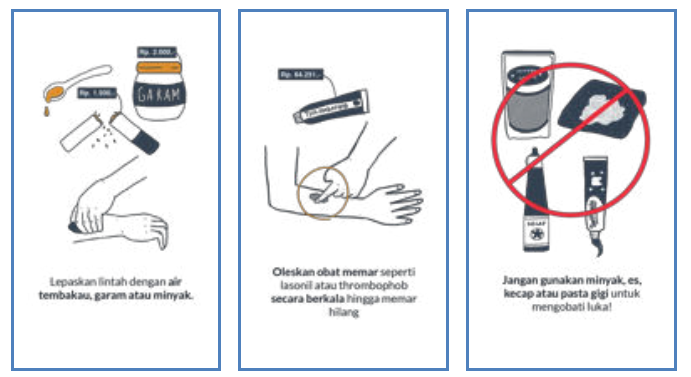

Gambar. 3 Contoh penerapan warna dalam ilustrasi.

Penggunaan aturan ketiga warna tersebut digunakan pada semua konten ilustrasi kecuali pada konten obat dan alat P3K. Hal tersebut dimaskudkan untuk memudahkan pengguna dalam mengenali obat-obatan dari warnanya.

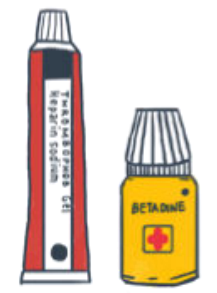

Gambar. 4 Contoh penerapan warna dalam ilustrasi obat.

\section{Warna}

Pengambilan warna diputuskan dengan membandingkan warna dari aplikasi eksisting. Semua eksisting menggunakan warna merah dan putih sebagai latar belakang dalam pemilihan warna dalam aplikasinya. Warna ini menandakan kegawatdaruratan, sehingga sesuai dnegan materi yang akan disampaikan. Eksisting juga memilih warna putih sebagai latar belakang untuk menonjolkan konten yang akan dibahas. Pada perancangan aplikasi ini, warna biru ditambahkan karena warna biru memiliki kekuatan menenangkan dan memberi rasa aman. Warna ini juga dipresepsikan kokoh dan dapat diandalkan (Samara, 2007). Selain itu warna biru, merah dan abu-abu yang digunakan dalam aplikasi ini bersifat unisex sehingga dapat digunakan secara umum.

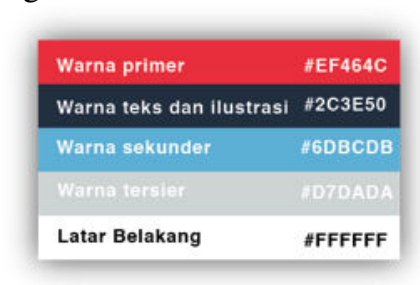

Gambar. 5 Palet warna aplikasi Saraya.

\section{E. Arsitektur Informasi Aplikasi}

$$
\begin{aligned}
& \text { User Flow } \\
& \text { Cari Gejala }
\end{aligned}
$$

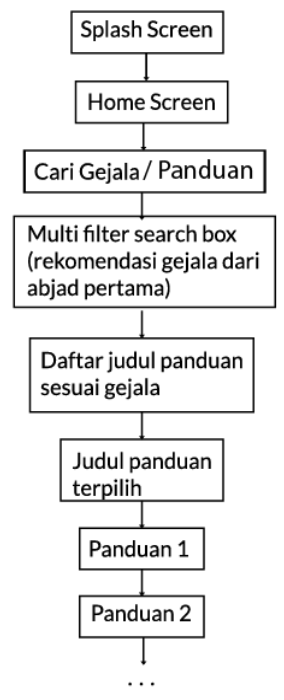

User Flow

Telepon Bantuan

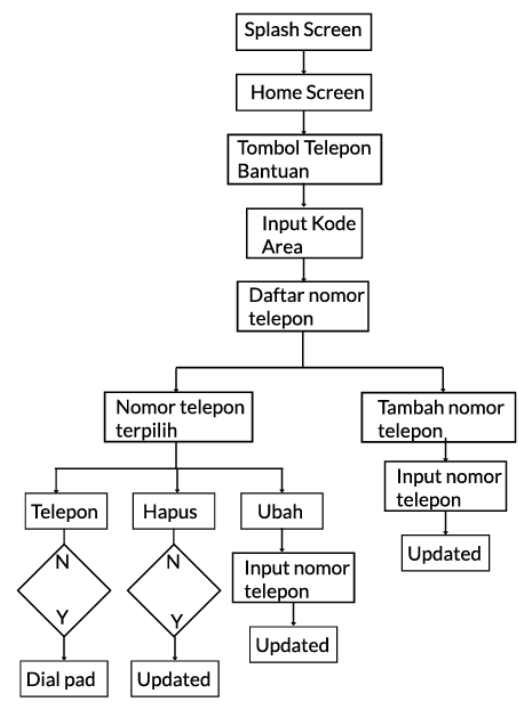

User Flow

Cari RS dan Apotek Terdekat

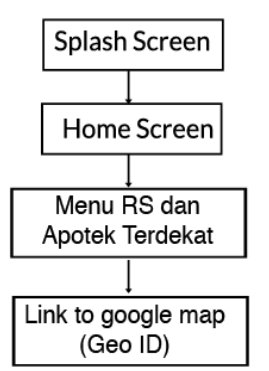


User Flow

Menu Penanganan

Penyakit

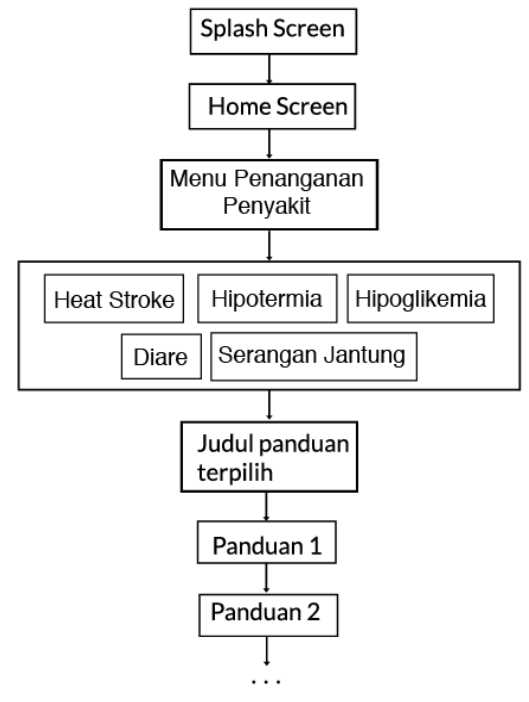

User Flow

Menu Luka Luar

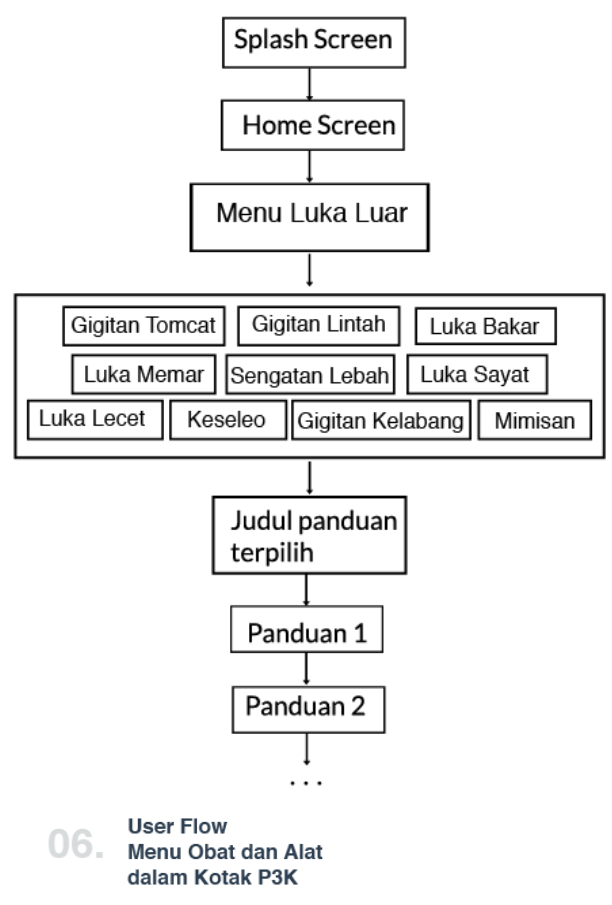

User Flow

Menu Perdarahan

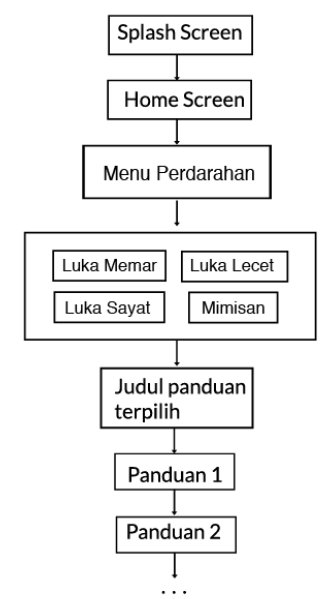

User Flow Menu Pingsan

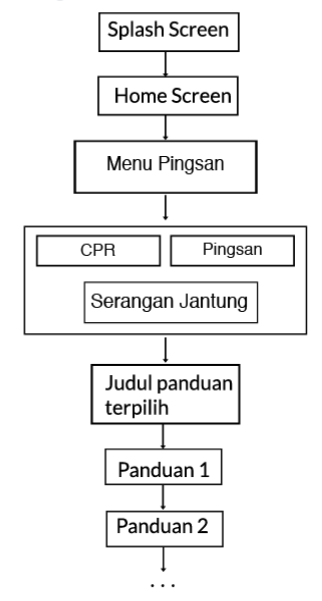

User Flow Menu Lainnya

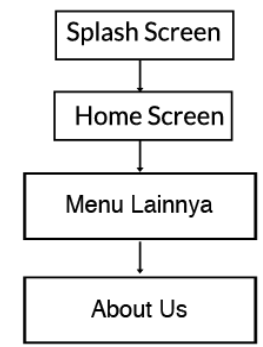

Gambar. 6 Aristektur informasi aplikasi.

\section{F. Desain Antarmuka}

Berdasarkan observasi studi eksisting dari media buku digital yang telah ada sebelumnya, elemen antarmuka yang dibutuhkan oleh buku digital interaktif terdiri dari logo dan ikon. Sketsa seperti yang terlihat pada Gambar (6)-(7).

\section{G.Konsep Bisnis dan Pengembangan}

1) Konsep Kerjasama

Konsep kerjasama yang akan dilakukan adalah konsep kerjasama dengan pihak sponsor dengan kriteria sponsor yang berhubungan dengan pertolongan pertama, baik fasilitas 
kesehatan atau perusahaan obat/suplemen kesehatan. Biaya yang disarankan penulis untuk dibayar oleh pihak sponsor adalah 20 juta per tahun.
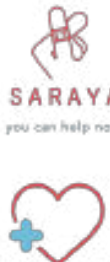

SARAYA SARAY A
SARAYA

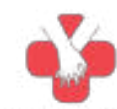

SARAYA

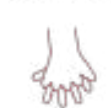

SARAYA

pousan help nou

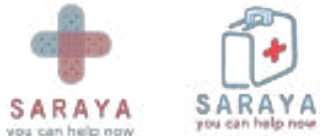

Gambar. 7 Alternatif desain logo aplikasi.
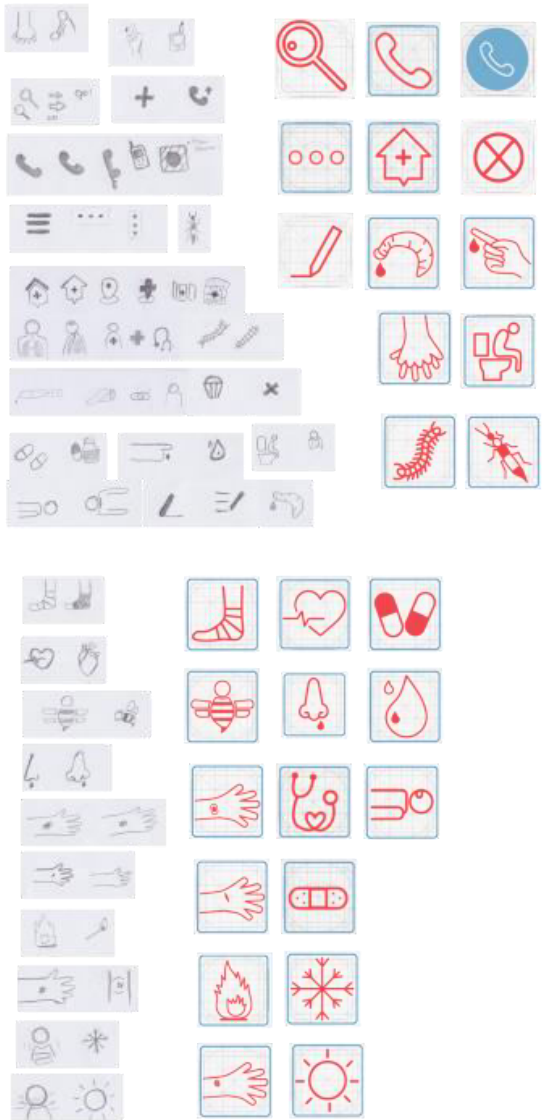

Gambar. 8 Sketsa dan desain final ikon aplikasi.

\section{H.Konsep Bisnis dan Pengembangan}

\section{1) Konsep Kerjasama}

Konsep kerjasama yang akan dilakukan adalah konsep kerjasama dengan pihak sponsor dengan kriteria sponsor yang berhubungan dengan pertolongan pertama, baik fasilitas kesehatan atau perusahaan obat/suplemen kesehatan. Biaya yang disarankan penulis untuk dibayar oleh pihak sponsor adalah 20 juta per tahun.

Sponsor akan mendapatkan fasilitas banner ads pada halaman utama dan rekomendasi pada konten panduan. Misalkan sponsor yang bekerjasama adalah klinik spesialis jantung, maka pada panduan aplikasi, akan direkomendasikan pada pengguna untuk mengunjungi klinik tersebut.

\section{2) Distribusi}

Pengguna dapat mengunduh sendiri aplikasi melalui portal distribusi aplikasi Android, yaitu Google Play Store baik melalui QR Code yang ada pada media promosi maupun pencarian manual pada Google Play Store. Mode yang digunakan dalam menjajakan aplikasi ini adalah free but with ads atau in-app advertising sehingga pengguna dapat tetap mengunduh secara gratis namun akan ada targeted ads yang muncul pada halaman aplikasi.

3) Konsep Pengembangan

a. Pengembangan materi pertolongan pertama untuk memperluas jangkauan materi

b. Pengembangan sistem berbagi untuk memperluas kesadaran masyarakat melalui sosial media dan memunculkan platform berbagi untuk kegiatan donasi

c. Pengembangan sistem pengingat untuk meningkatkan keterikatan atara aplikasi dan pengguna.

d. Pengembangan kerjasama dengan layanan kesehatan meliputi kerjasama tidak langsung berupa iklan dan kerjasama langsung berupa kerjasama dalam memberikan layanan antri online melalui Saraya.

\section{PEMBAHASAN DESAIN}

Hasil desain adalah berupa konten narasi, aset visual ilustrasi panduan, dan elemen antarmuka yang diimplementasikan pada aplikasi Saraya.

\section{A. Hasil Akhir Desain Layout Ilustrasi}

Desain ilustrasi dalam aplikasi Saraya menggunakan gaya line art dengan menggunakan satu warna dasar yaitu biru (\#2C3E50) untuk membuat pengguna fokus pada konten yang disampaikan. Latar belakang putih juga digunakan supaya konten yang dipaparkan menonjol. Penggunaan warna merah sebagai tanda larangan dan kuning sebagai anjuran atau penanda benar pada ilustrasi memberikan kemudahan dalam pemahaman materi.

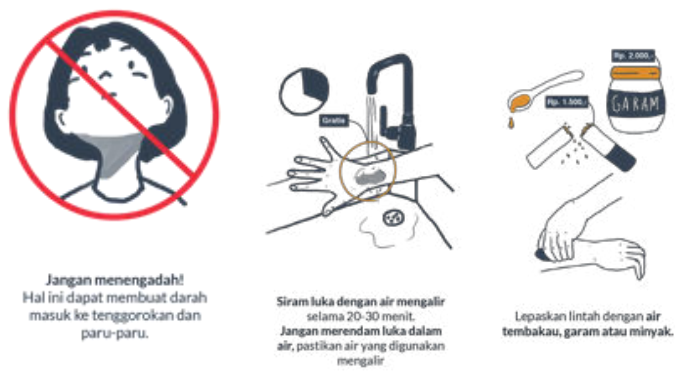

Gambar. 9 Contoh ilustrasi dalam aplikasi (a) penggunaan warna merah pada ilustrasi (b) penggunaan warna kuning dalam ilustrasi dengan isyarat lingkaran (c) penggunaan warna kuning dalam warna ilustrasi

Tipografi yang diterapkan dalam aplikasi adalah jenis sanserif dimana font Helvetica Bold digunakan sebagai judul konten, font Lato Regular digunakan sebagai nama ikon, perintah, serta konten panduan dan font Lato bold digunakan sebagai penekanan dalam konten. 


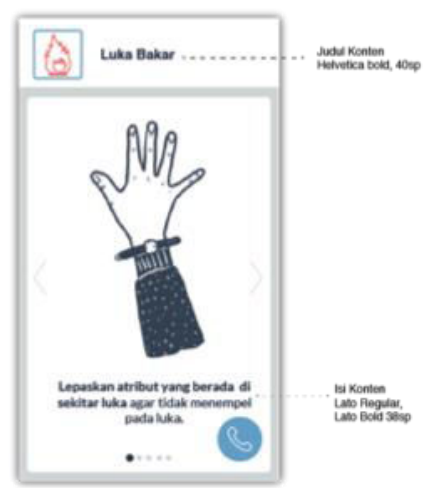

Gambar 10. Contoh penggunaan tipografi dalam aplikasi.

\section{B. Implementasi}

Ilustrasi dan elemen-elemen antarmuka kemudian diemplementasikan dalam aplikasi. Gambar (10)-(14) menampilkan implementasi beserta penjelasannya.
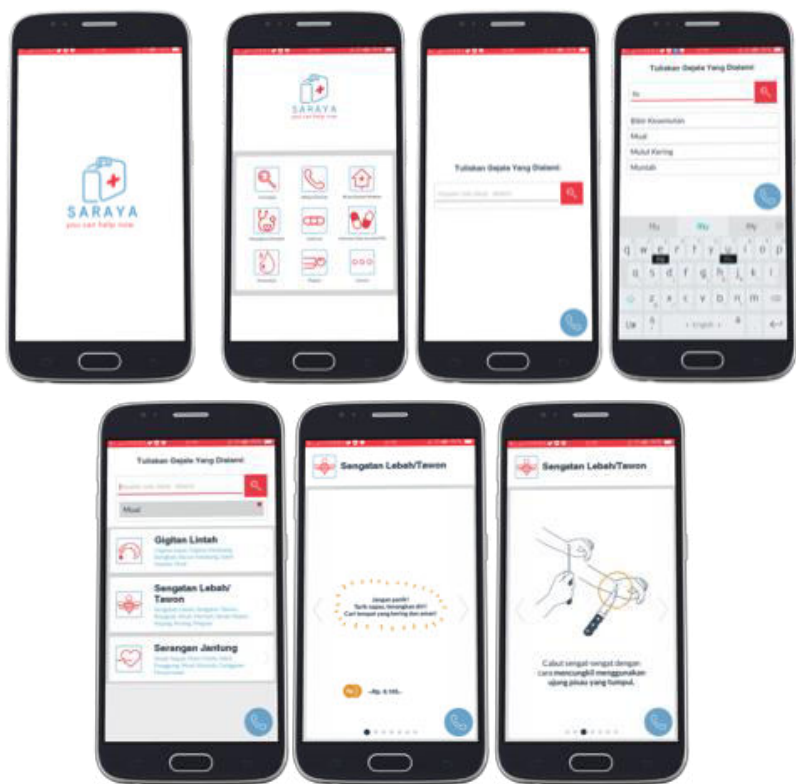

Gambar 11. Tampilan dari halaman utama menuju ke panduan melaui pencarian gejala.

Pada Gambar (10) ditampilkan implementasi dari elemen antarmuka yang telah diusun dalam aplikasi, yaitu elemen antarmuka dari awal pengguna membuka aplikasi, kemudian melihat panduan melalui opsi pencarian gejala. Penggunaan rekomendasi pencarian mempermudah pengguna dalam menemukan panduan yang dinginkan. Penggunaan multiple keyword dalam pencarian juga memudahkan dalam mengeleminasi daftar panduan yang dicari.

Pada Gambar (11), ditampilkan implementasi elemen antarmuka dimana pengguna menemukan panduan melalui sub menu pencarian panduan berdasar kategori. Pada opsi perkategori, pengguna dapat dengan mudah menemukan daftar panduan tanpa harus mencari gejala.

Pada Gambar (12) ditampilkan implementasi elemen antarmuka saat pengguna memutuskan mencari apotek dan RS terdekat yang akan langsung diarahkan ke Google Maps dengan melacak lokasi pengguna (Geo ID).

Pada Gambar (13) dan (14) ditampilkan implementasi elemen antarmuka yang ada pada opsi telepon darurat, yaitu opsi panggilan darurat melalui aplikasi seperti pada Gambar (13) yang bisa diakses melalui menu utama maupun widget telepon. Pada Gambar (14) ditampilkan implementasi elemen antarmuka opsi menu pengubahan dan penghapusan kontak untuk semakin mempermudah pengguna dalam menghadapi situasi darurat.
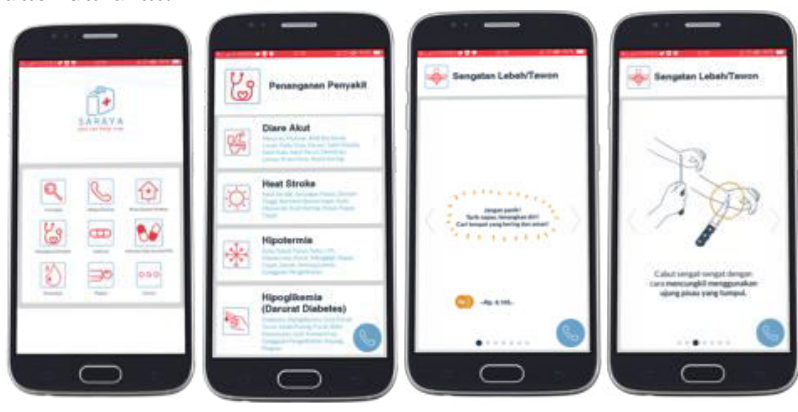

Gambar 12. Tampilan dari halaman utama menuju ke panduan melalui kategori panduan.
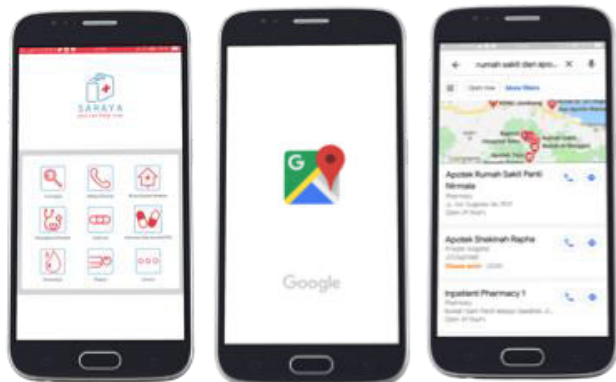

Gambar 13 Tampilan dari menu utama menuju ke petunjuk RS dan apotek terdekat.
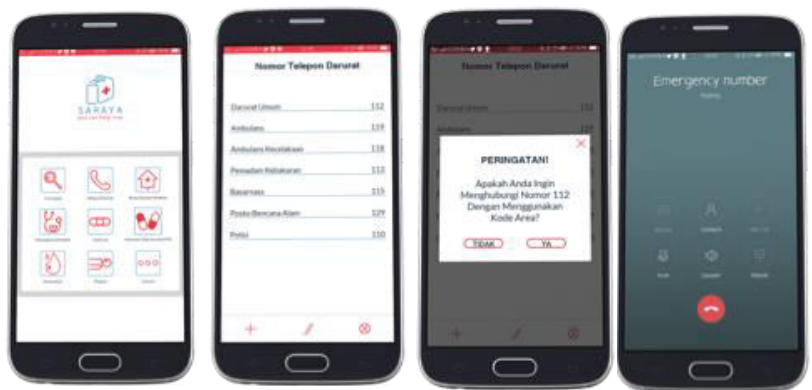

Gambar 14. Tampilan dari menu utama menuju ke telepon darurat.
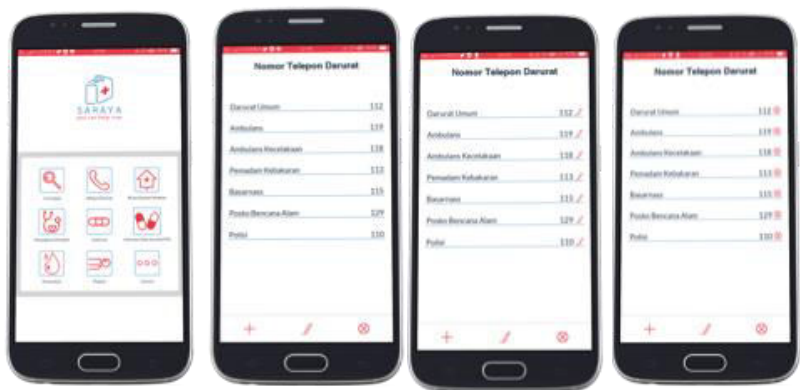

Gambar 15. Tampilan menu utama menuju ke opsi menu telepon darurat (a) pengubahan dta telepon (b) penghapusan data telepon.

\section{KESIMPULAN}

Adanya alternatif panduan pertolongan perama dalam bentuk mobile application dapat menjadi solusi pembelajaran mandiri bagi orang awam. Konsep komunikatif dan familiar 
pada Aplikasi Saraya telah berhasil dengan nilai rata-rata 4.1 dari 5 dengan standar deviasi 0.6. Aplikasi Saraya sudah komunikatif $(80,6 \%)$ dan familiar $(82,6 \%)$ bagi orang awam, baik secara konten maupun media sehingga menjawab permasalahan yang ada. Penggunaan typeface jenis san-serif dalam aplikasi membuat visualisasi konten mudah dibaca dan jelas sehingga mudah dimengerti. Penggunaan ilustrasi dalam visualisasi panduan sangat memperjelas konten yang dibawakan. Namun, terdapat beberapa hal yang dapat dilakukan untuk menunjang aplikasi ini agar menjadi lebih baik yaitu melakukan pengembangan konsep sesuai rencana pengembangan konsep aplikasi, melakukan pengembangan aplikasi untuk mengikat pengguna dan memikat sponsor serta melakukan perancangan aplikasi sesuai jenjang pendidikan dan bertahap, sehingga materi yang diberikan dapat menjadi sebiah kurikulum yang tersruktur.

\section{DAFTAR PUSTAKA}

[1] S. Hoober, "How Do Users Really Hold Mobile Devices," UX Matters. [Online]. Available: https://www.uxmatters.com/mt/archives/2013/02/how-do-users-reallyhold-mobile-devices.php.

[2] S. D. Quinn, "Poynter 'EyeTrack: Tablet' research shows horizontal swiping instinct for photo galleries," Poynter. [Online]. Available: https://www.poynter.org/news/poynter-eyetrack-tablet-research-showshorizontal-swiping-instinct-photo-galleries. [Accessed: 15-Mar-2018]. 